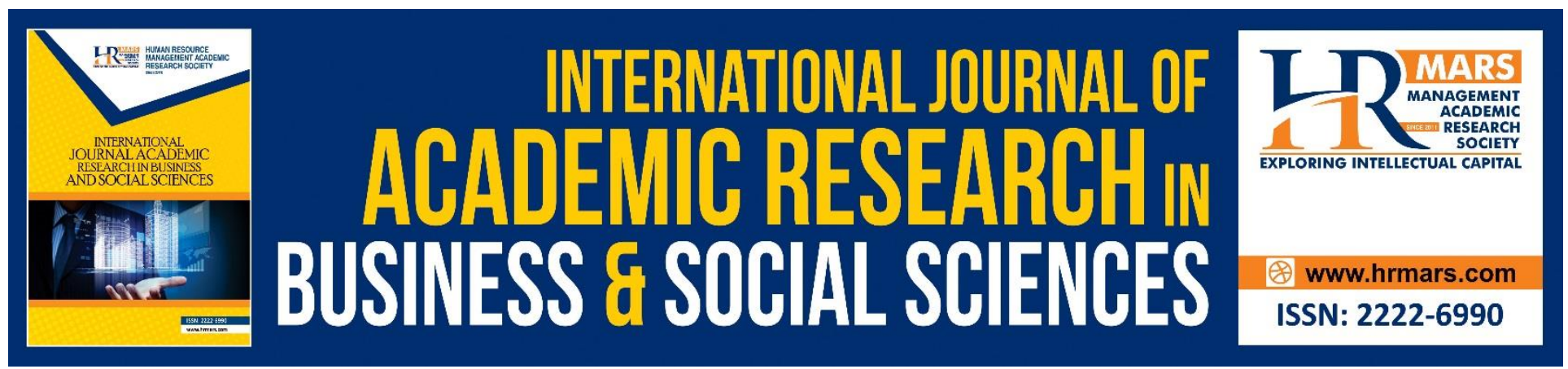

\title{
A Study on the Effectiveness of Global Zakat Game (GZG) as a Zakat Teaching and Learning Tool
}

Nurkhamimi Zainuddin, Azman Ab. Rahman, Muhammad Sabri Sahrir, Hasanah Abd Khafiz

To Link this Article: http://dx.doi.org/10.6007/IJARBSS/v9-i3/5871

DOI: $10.6007 /$ IJARBSS/v9-i3/5871

Received: 30 Jan 2019, Revised: 10 Feb 2019, Accepted: 28 Feb 2019

Published Online: 23 March 2019

In-Text Citation: (Zainuddin, Rahman, Sahrir, \& Khafiz, 2019)

To Cite this Article: Zainuddin, N., Rahman, A. A., Sahrir, M. S., \& Khafiz, H. A. (2019). A Study on the Effectiveness of Global Zakat Game (GZG) as a Zakat Teaching and Learning Tool. International Journal of Academic Research Business and Social Sciences, 9(3), 1488-1500.

Copyright: (C) 2019 The Author(s)

Published by Human Resource Management Academic Research Society (www.hrmars.com)

This article is published under the Creative Commons Attribution (CC BY 4.0) license. Anyone may reproduce, distribute, translate and create derivative works of this article (for both commercial and non-commercial purposes), subject to full attribution to the original publication and authors. The full terms of this license may be seen

at: http://creativecommons.org/licences/by/4.0/legalcode

Vol. 9, No. 3, 2019, Pg. 1488 - 1500

http://hrmars.com/index.php/pages/detail/IJARBSS

JOURNAL HOMEPAGE

Full Terms \& Conditions of access and use can be found at http://hrmars.com/index.php/pages/detail/publication-ethics 


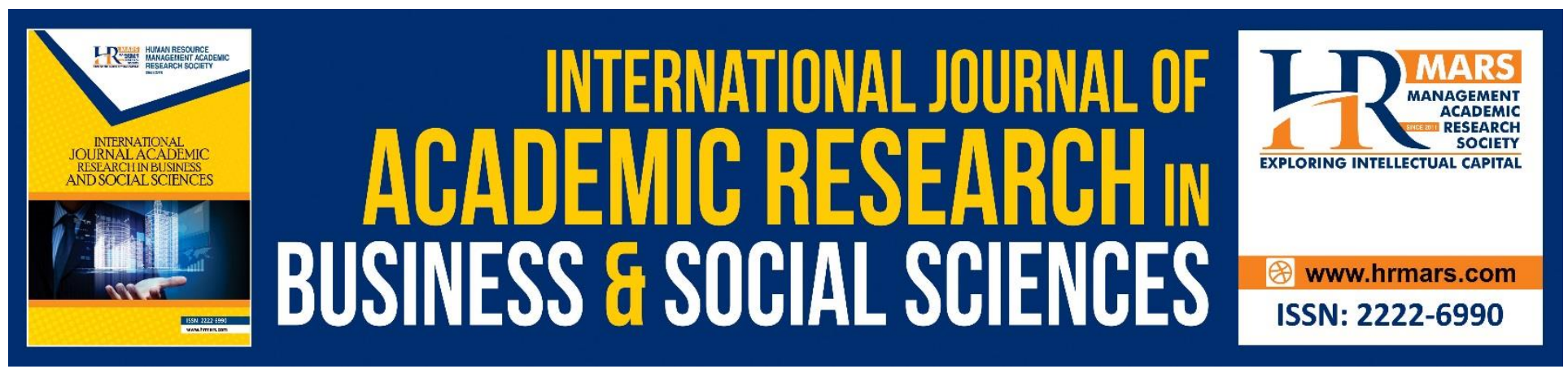

\title{
A Study on the Effectiveness of Global Zakat Game (GZG) as a Zakat Teaching and Learning Tool
}

\author{
Nurkhamimi Zainuddin, Azman Ab. Rahman \\ Universiti Sains Islam Malaysia, Malaysia \\ Muhammad Sabri Sahrir \\ International Islamic University Malaysia, Malaysia \\ Hasanah Abd Khafiz \\ Universiti Kebangsaan Malaysia, Malaysia
}

\begin{abstract}
Board games have become one of the useful tools in teaching and learning. Many instructors and educators have chosen to use board games to enhance the way of delivering course contents. An effective board game will help students understand the concept quickly and get involved in experiential learning, where students can manage and solve problems in an actual situation. This study will focus on the effectiveness of board games, namely Global Zakat Game (GZG) as a Zakat teaching and learning tool. A questionnaire has been used to analyze the effectiveness of using GZG as a Zakat teaching and learning tool in increasing students' comprehension and understanding on Zakat concepts. The respondents gave a few suggestions and comments on how to improve the GZG for the betterment of the Zakat teaching and learning. The result obtained indicated that the use of GZG as a Zakat teaching and learning tool has a positive impact on students' learning as it helps students learn about Zakat concepts. A majority of the respondents mentioned that they enjoyed playing GZG as it utilizes experiential learning and can be used as an edutainment tool for students and society that is suitable for all ages.
\end{abstract}

Keywords: Board games, Zakat, Teaching and learning, Edutainment, Gamification

\section{Introduction}

Education today is very challenging. In an effort to educate the young generation, various training tools have been used. These materials have been designed to facilitate students in understanding a subject. Previously, many instructors assumed that students will be able to understand the whole teaching and learning goals through traditional training methods, but in reality, many students only 
INTERNATIONAL JOURNAL OF ACADEMIC RESEARCH IN BUSINESS AND SOCIAL SCIENCES Vol. 9, No. 3, March, 2019, E-ISSN: 222 2-6990 @ 2019 HRMARS

manage to achieve partial goals; with some not achieving any. Therefore, an effective approach should be used to encourage and inspire during teaching (Zainuddin \& Idrus, 2017).

The implementation of tools such as board games provide a non-threatening, playful and competitive environment where students can learn from their mistakes due to their weaknesses and failures in achieving learning goals (Treher, 2011). A board game is a game involving a counter or token that is placed or moved on a board game provided by a set of instructions. Board games can be classified into two categories that reflect the realities of life or vice versa (Carlos \& Awad-Aubad, 2007).

Global Zakat Game (GZG) is also referred to as a board game or an exercise presents a blend of two streams: education and entertainment merging into one (Edutainment). Edutainment is applied in order to teach learners how they should use their own knowledge, analyzing things that they learned, combining things that they perceived and evaluating things that they learned (Charsky, 2010). GZG can be used to supplement existing learning approaches or integrated into existing curricula. According to Lee (2016), some pedagogical advantages of board games include:

- Encouragement of learners to take a problem solving approach in learning

- Instant feedback to correct misconceptions and promote formation of concepts thus increasing learners' understanding of a subject area.

- Increased retention of information through learning by game-playing

- Aid in acquisition and development of cognitive abilities that are not formally taught in education.

- Fostering collaborative learning among peers.

- Promotes deep learning by arousing learners' curiosity on certain subjects.

- Transforming entertaining play to productive play and extending learning into gaming.

In an era when many students are oriented towards games or simulation, it is the best opportunity to use board games as a teaching and learning tool. The use of board games are becoming the latest phenomena to try to engage the students to fully learn a certain subject. According to Reid et al. (2012) it provides a better learning platform compared to traditional teaching methods. Furthermore, Carlos \& Awad-Aubad (2007) pointed out that the traditional teacher-centred learning should be complemented with student-centred board games to give students or players the ability to practice self-learning. It can be concluded that learning through board games give a positive impact to students learning abilities.

Too, Cook \& Olson (2006) indicated that board games are important tools to provide hands-on and heads-on skills and knowledge development for people on all subjects, as well as very useful, effective and enjoyable for all ages. This is supported by Ab Rahman et al. (2017) who claimed that the use of games as a teaching tool has attracted $96 \%$ of the students' interests in learning compared to usual.

\section{Global Zakat Game (GZG) Design}

The idea of producing this product arised when looking at the Zakat collection in Malaysia, which has not reached the targeted level. The statistics of Zakat payers in the Federal Territory 2015 shows that 
only 166,787 people pay Zakat to PPZ-MAIWP from 1.7 million people (Wahab \& Borhan, 2014). Among the factors contributing to the problem are the level of understanding and awareness of the community on the obligation of Zakat is still low.

Hence, awareness and understanding on the importance and obligation of Zakat should be practised at all age levels, as early as in school to working environment. On $1^{\text {st }}$ August 2016, the researchers from Universiti Sains Islam Malaysia (USIM) have discussed in developing a new innovation in a form of game that can be used in the Malaysian education system. Various teaching and learning methods have been used by teachers and educators in understanding the students, generally in the subject of Islamic education, primarily in the field of Zakat.

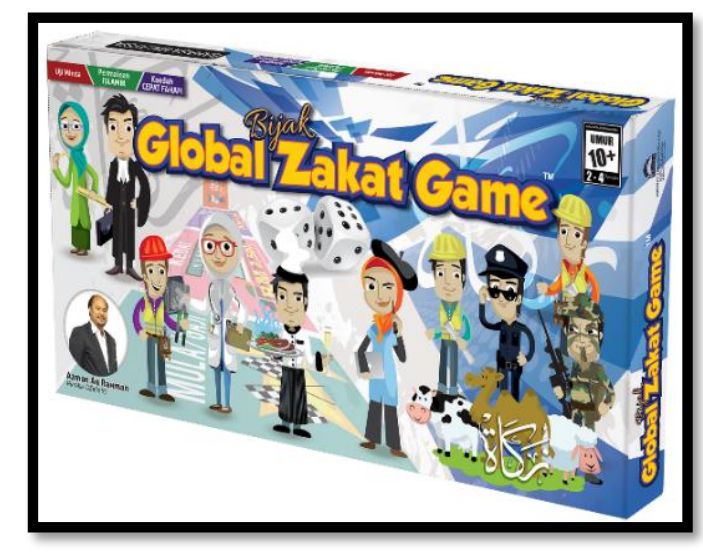

Fig. 1: Global Zakat Game box

GZG (Figure 1) is an interactive and informative board game, which can be used as a new Zakat teaching and learning aid. By playing this game, players will be able to understand the concept of Zakat and strengthen their calculation skills involving calculation of agricultural, livestock, businesses, gold and silver and buried treasure Zakat. It is hoped that GZG will give benefits and insights on Zakat management in Islam. The components of GZG are as shown in Table 1: 
INTERNATIONAL JOURNAL OF ACADEMIC RESEARCH IN BUSINESS AND SOCIAL SCIENCES Vol. 9, No. 3, March, 2019, E-ISSN: 222 2-6990 @ 2019 HRMARS

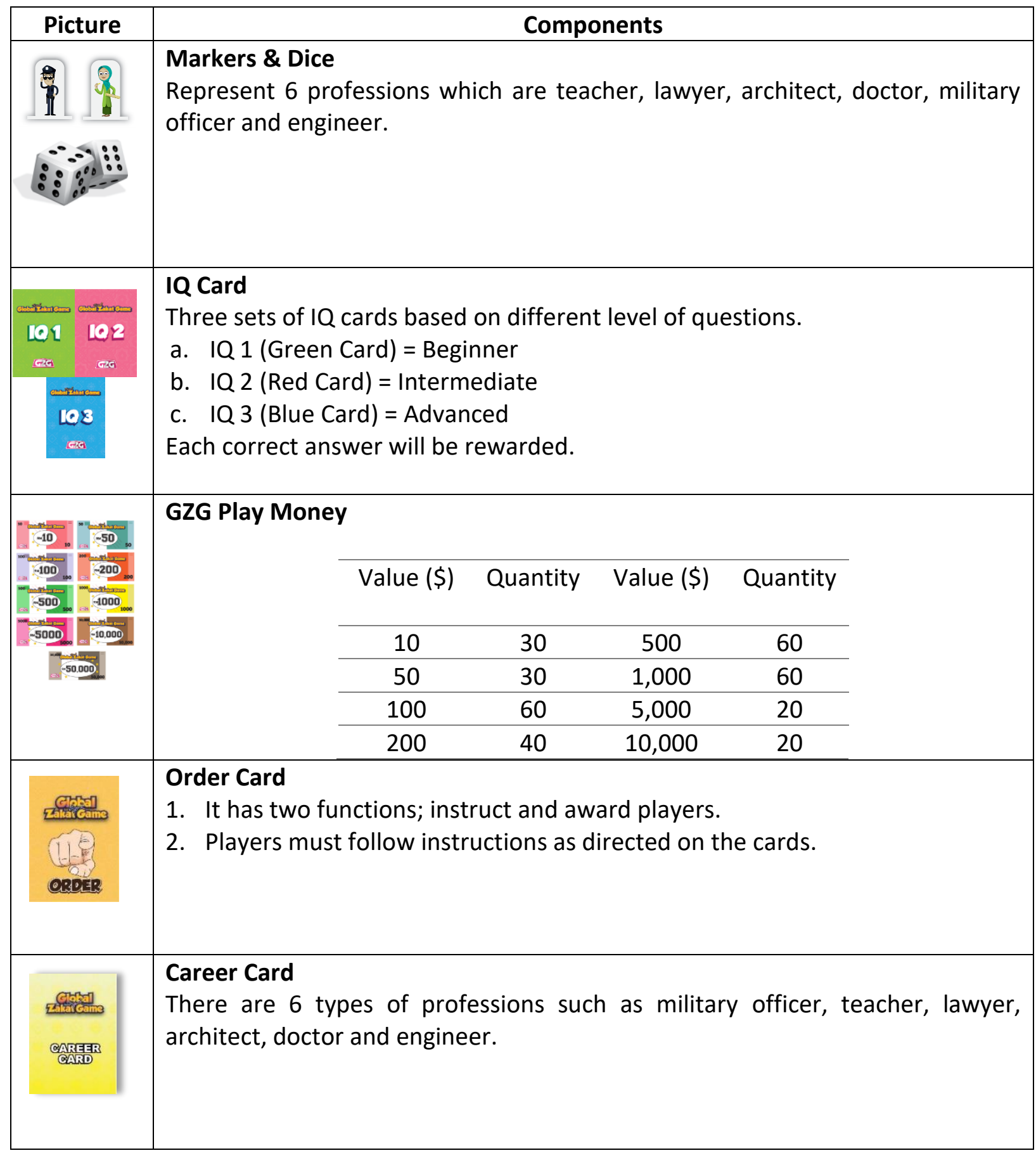


INTERNATIONAL JOURNAL OF ACADEMIC RESEARCH IN BUSINESS AND SOCIAL SCIENCES

Vol. 9, No. 3, March, 2019, E-ISSN: 222 2-6990 @ 2019 HRMARS

\begin{tabular}{|c|c|}
\hline 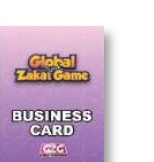 & $\begin{array}{l}\text { Business Card \& Reward Card } \\
\text { 1. Players get cards as proof of purchase if they successfully buy business. } \\
\text { 2. It determines value of outcome and product for each business. }\end{array}$ \\
\hline 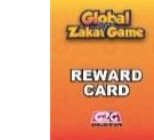 & \\
\hline $\begin{array}{l}\text { Grial } \\
\text { Zakarcame } \\
\text { ZAKAT } \\
\text { GARD } \\
\text { CEC }\end{array}$ & $\begin{array}{l}\text { Zakat Cards } \\
\text { Six sets of Zakat cards which include } 6 \text { types of Zakat al-mal: } \\
\text { 1. Zakat on business } \\
\text { 2. Zakat on gold and silver } \\
\text { 3. Zakat on livestock } \\
\text { 4. Zakat on agriculture } \\
\text { 5. Zakat on Rikaz \& Ma'adin } \\
\text { 6. Zakat on income }\end{array}$ \\
\hline
\end{tabular}

\section{GZG General Rules}

Table 1: GZG Components

1. Questions are based on three different IQ levels i.e.; IQ 1 (Green), IQ 2 (Red) and IQ 3 (Blue).

2. The game has two sections, basic and advance section.

3. Players can proceed to move from basic section to advance section once they successfully collect a total amount of $\$ 5000$ cash and above.

4. Wealth Acquisition - Three methods of wealth acquisition:

a. Salary - Income is paid when players land on the spaces marked "salary" which is based on careers.

b. Business - Revenue from product and business.

c. Reward - If players answer question on IQ card correctly, they are given an option to either keep award cards or redeem cash. The value of cash is based on the IQ card level.

i. IQ Card $1=\$ 100$

ii. IQ Card $2=\$ 200$

iii. IQ Card $3=\$ 300$

5. Dice System - Dice is used for each round to determine spaces that players can pass over. If a player rolls a two of a kind (both dice show the same number), they can roll the dice once again for additional moves. However, if the dice shows doubles for two times in a row, the player will lose their turn.

6. Throughout the game, players will pass over labelled spaces. Each space has different meanings as follows:

a. Start - The game starts from here.

b. Salary - Players are paid salary by the bank (Zakat agent) based on their careers.

c. Fines - Players are required to pay fines.

d. Order - Players are required to pick order cards and follow instructions. 
e. Business - There are three functions of business spaces:

i. Players who lands on "unowned" business spaces are given an option whether to buy business or not by using their salary or wealth generated from businesses.

ii. Players who land on their own business spaces receive revenues as stated in business cards.

iii. Players who land on other players' business spaces must pay for that product (as stated in business card) to the owners.

f. IQ - IQ spaces are labelled with different colours. Each respective colour has different level of questions. Each correct answer will be rewarded. However, there is no penalty for false answer given.

* Players have an option to either keep the reward cards or redeem cash.

g. Zakat Calculation - Players who land at this space must do the followings:

i. Calculating all their wealth and if the amount reaches nisab (the minimum amount for a Muslim net worth to be obliged to pay Zakat), players must make Zakat payment to the bank (Zakat agent) in cash.

ii. Record the amount of Zakat payment.

iii. If the players do not have cash, they are considered on debt and need to pay Zakat when cash is available.

h. Failed To Pay Zakat - Lose one round. If player insists to continue the game without getting suspended for one round, player must pay $\$ 200$ for arrears/outstanding Zakat payment.

i. Car Breakdown - Lose one round or pay $\$ 500$.

7. Players can sell their business spaces to bank officer or other players at half price from the real value.

\section{Methodology}

On $8^{\text {th }}$ November 2017, a national-level GZG contest (Figure 2) was organized in Universiti Sains Islam Malaysia (USIM). Various types of participants from different education levels (primary schools, secondary schools and higher education institutions), as well as the public have participated in this contest. The researchers took one hour to give short briefing on how to play GZG and asked permission from the participants to be respondents for the study. Once the participants had formed their groups, the contest began. During the contest, the researchers conducted observations to investigate the engagement of participants and their achievements. Data was collected after each game had finished. All respondents were asked to fill in a paper-based questionnaire given by the researchers. 


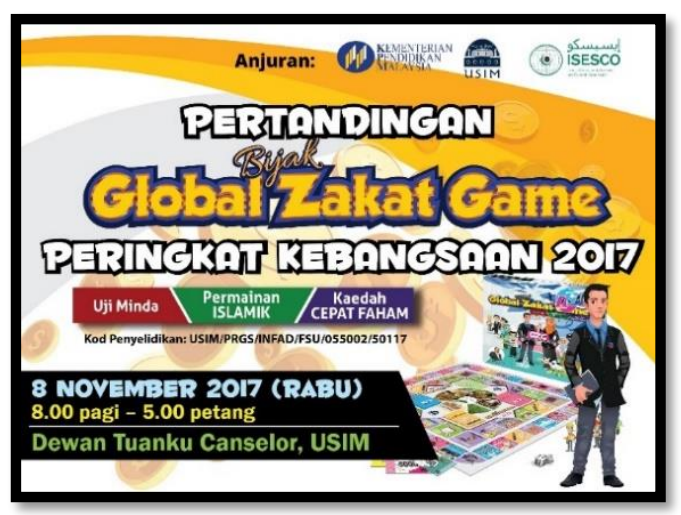

Fig. 2: GZG contest poster 2017

The questionnaire was developed on the basis of the literature review and validated by experts who have academic or industrial backgrounds and abundant experience in teaching or conducting professional practice in the field of Zakat. The questionnaire consisted of the following sections (Table 2):

Table 2: Items of the questionnaire

\section{Section A}

Characterization of the respondents in terms of age, sex and institution.

\section{Section B}

Responses to questions related to the effectiveness of GZG as a Zakat teaching and learning tool ranked on a 5-point Likert scale (Strongly disagree, disagree, neutral, agree, strongly agree).

\section{Section C}

Suggestions from the respondents to improve the GZG for the betterment of Zakat teaching and learning (Open ended).

The collected data was analysed using the IBM SPSS Statistics 20 software. A descriptive analysis was performed in order to characterize the behavior of each variable measured.

\section{Result}

The results are analysed as follows:

\section{Demographic profile of respondents}

A total of 235 respondents between the age of 10 to 47 years old (107 female and 128 male) volunteered for the study. It can be observed that most of the participants came from secondary schools (34.9\%), followed by primary schools (19.6\%), higher education institutions (31.9\%) and others (13.6\%) as presented by Table 3. 
INTERNATIONAL JOURNAL OF ACADEMIC RESEARCH IN BUSINESS AND SOCIAL SCIENCES

Vol. 9, No. 3, March, 2019, E-ISSN: 222 2-6990 @ 2019 HRMARS

Table 3: Respondents demographics

\begin{tabular}{ccc} 
& Frequency & Percent \\
\hline Primary Schools & 46 & 19.6 \\
\hline Secondary Schools & 82 & 34.9 \\
\hline $\begin{array}{c}\text { Higher Education } \\
\text { Institutions }\end{array}$ & 75 & 31.9 \\
\hline Others & 32 & 13.6 \\
\hline Total & 235 & 100.0 \\
\hline
\end{tabular}

The effectiveness of GZG as a Zakat teaching and learning tool

Table 4 indicates the responses from the respondents regarding the effectiveness of GZG as a Zakat teaching and learning tool. $52.8 \%$ of the respondents strongly agree that their understanding towards Zakat increased after playing GZG and 52.3\% mentioned that GZG had increased their interest in studying Zakat topics because it uses all Zakat learning syllabus taught in schools. 45.1\% of the respondents feel that they are able to master the theory, concept and the calculation of Zakat as a whole after playing GZG. 64.7\% responded that GZG is suitable for all ages and can be used as an edutainment tool for students and society.

Table 4: Responses from the respondents

\begin{tabular}{|c|c|c|c|c|c|c|}
\hline \multirow[t]{2}{*}{ No } & \multirow[t]{2}{*}{ Item } & \multirow{2}{*}{$\begin{array}{c}\text { SD } \\
1\end{array}$} & \multirow{2}{*}{$\begin{array}{l}\mathbf{D} \\
\mathbf{2}\end{array}$} & \multirow{2}{*}{$\begin{array}{l}\mathbf{N} \\
\mathbf{3}\end{array}$} & \multirow{2}{*}{$\begin{array}{l}\text { A } \\
4\end{array}$} & \multirow{2}{*}{$\begin{array}{c}\text { SA } \\
5\end{array}$} \\
\hline & & & & & & \\
\hline 1 & $\begin{array}{l}\text { My understanding of Zakat increased after playing } \\
\text { GZG }\end{array}$ & $0.4 \%$ & $0.4 \%$ & $5.5 \%$ & $40.9 \%$ & $52.8 \%$ \\
\hline 2 & $\begin{array}{l}\text { GZG can increase my interest in studying Zakat } \\
\text { topics }\end{array}$ & $0.4 \%$ & $1.3 \%$ & $9.8 \%$ & $36.2 \%$ & $52.3 \%$ \\
\hline 3 & $\begin{array}{l}\text { GZG used all Zakat learning syllabus taught in my } \\
\text { school }\end{array}$ & $0.4 \%$ & $2.1 \%$ & $8.9 \%$ & $37 \%$ & $51.5 \%$ \\
\hline 4 & $\begin{array}{l}\text { I am able to master the theory and concept of Zakat } \\
\text { as a whole after playing GZG }\end{array}$ & $1.7 \%$ & $3.4 \%$ & $21.3 \%$ & $45.1 \%$ & $28.5 \%$ \\
\hline 5 & I know how to calculate Zakat after using GZG & $0 \%$ & $1.7 \%$ & $17.9 \%$ & $40.4 \%$ & $40 \%$ \\
\hline 6 & GZG is suitable for all ages & $0 \%$ & $1.3 \%$ & $6 \%$ & $28.1 \%$ & $64.7 \%$ \\
\hline 7 & $\begin{array}{l}\text { GZG can be used as an edutainment tool for } \\
\text { students and society }\end{array}$ & $0.4 \%$ & $0.9 \%$ & $1.7 \%$ & $27.2 \%$ & $69.8 \%$ \\
\hline
\end{tabular}

Suggestions to improve the GZG for the betterment of Zakat teaching and learning Table 5 shows selected suggestions from respondents to improve the GZG for the betterment of Zakat teaching and learning. 
INTERNATIONAL JOURNAL OF ACADEMIC RESEARCH IN BUSINESS AND SOCIAL SCIENCES Vol. 9, No. 3, March, 2019, E-ISSN: 222 2-6990 @ 2019 HRMARS

Table 5: Responses from the respondents

\begin{tabular}{|c|c|c|}
\hline Respondents & Institution & Suggestions \\
\hline No. 1 & Sek Sri Seremban & $\begin{array}{l}\text { Great and challenging game. It increases my } \\
\text { knowledge about Zakat. }\end{array}$ \\
\hline No. 3 & Sek Sri Seremban & Needs to add more IQ boxes. \\
\hline No. 11 & $\begin{array}{c}\text { Pusat Zakat Negeri } \\
\text { Sembilan }\end{array}$ & $\begin{array}{l}\text { A very good Islamic product for the whole family } \\
\text { and public workers. }\end{array}$ \\
\hline No. 19 & $\begin{array}{l}\text { Persatuan Orang Pekak } \\
\text { Negeri Sembilan }\end{array}$ & $\begin{array}{l}\text { Excellent. Kindly make a version for the deaf } \\
\text { people }\end{array}$ \\
\hline No. 40 & $\begin{array}{l}\text { Sekolah Rendah Agama } \\
\text { Al-Islahiyah }\end{array}$ & Increase salary for every character. \\
\hline No. 42 & $\begin{array}{l}\text { Sekolah Rendah Agama } \\
\text { Al-Islahiyah }\end{array}$ & $\begin{array}{l}\text { It is more interesting to use statues for animals } \\
\text { and gold bars. }\end{array}$ \\
\hline No. 49 & $\begin{array}{l}\text { Sekolah Rendah } \\
\text { Setiabudi }\end{array}$ & $\begin{array}{l}\text { I think GZG is great and easy to understand. I } \\
\text { recommend that you build a Jawi version. }\end{array}$ \\
\hline No. 52 & $\begin{array}{l}\text { Sekolah Kebangsaan } \\
\text { Telok Kemang }\end{array}$ & $\begin{array}{l}\text { GZG needs to be sold in every country and } \\
\text { designed in all languages so that Muslims } \\
\text { understand the concept of Zakat. }\end{array}$ \\
\hline No. 53 & $\begin{array}{l}\text { Sekolah Kebangsaan } \\
\text { Telok Kemang }\end{array}$ & I suggest to have a more difficult IQ 4 level. \\
\hline No. 65 & $\begin{array}{l}\text { Pusat Kutipan Zakat } \\
\text { Pahang }\end{array}$ & $\begin{array}{l}\text { The Nisab rate for livestock Zakat needs to be } \\
\text { scrutinized so it will not cause players' confusion. }\end{array}$ \\
\hline No. 66 & $\begin{array}{l}\text { Pusat Kutipan Zakat } \\
\text { Pahang }\end{array}$ & $\begin{array}{l}\text { I suggest to create GZG games online that allows } \\
\text { multi players. }\end{array}$ \\
\hline No. 94 & Kolej PERMATA Insan & $\begin{array}{l}\text { Good gamification effort, however rules need to } \\
\text { be clearer. }\end{array}$ \\
\hline No. 119 & $\begin{array}{l}\text { Sekolah Menengah } \\
\text { Agama Nilai }\end{array}$ & $\begin{array}{l}\text { I recommend that each set to be bundled with } 3 \\
\text { languages: English, Arabic and Bahasa Malaysia. }\end{array}$ \\
\hline No. 120 & $\begin{array}{l}\text { SMK Agama Bandar } \\
\text { Penawar }\end{array}$ & $\begin{array}{l}\text { Make in bilingual and sell online for easy } \\
\text { purchase. }\end{array}$ \\
\hline No. 126 & $\begin{array}{l}\text { SMKA Maahad } \\
\text { Hamidiah }\end{array}$ & $\begin{array}{l}\text { The game takes quite a while. Orders and rules } \\
\text { need to be clearer. }\end{array}$ \\
\hline No. 139 & $\begin{array}{l}\text { SMKA Sheikh Haji } \\
\text { Mohd Said }\end{array}$ & $\begin{array}{l}\text { Very interesting. GZG can be used for the 21st } \\
\text { century teaching and learning tool. }\end{array}$ \\
\hline No. 146 & $\begin{array}{l}\text { Sekolah Menengah } \\
\text { Islam Hidayah }\end{array}$ & Create a mobile application for GZG. \\
\hline No. 152 & $\begin{array}{l}\text { Sekolah Agama } \\
\text { Menengah Sungai Haji } \\
\text { Dorani, Sabak Bernam }\end{array}$ & $\begin{array}{l}\text { Introduce the game at all schools and conduct } \\
\text { workshops. }\end{array}$ \\
\hline No. 174 & $\begin{array}{l}\text { Universiti Sultan Azlan } \\
\text { Shah (USAS) }\end{array}$ & Larger board size and numbers. \\
\hline
\end{tabular}


INTERNATIONAL JOURNAL OF ACADEMIC RESEARCH IN BUSINESS AND SOCIAL SCIENCES Vol. 9, No. 3, March, 2019, E-ISSN: 2222-6990 @ 2019 HRMARS

\begin{tabular}{cll} 
No. 222 & UiTM Puncak Alam & $\begin{array}{l}\text { Good alternative to attract the public interest in } \\
\text { Zakat. Good job. }\end{array}$ \\
\hline No. 234 & $\begin{aligned} \text { Universiti Pendidikan } \\
\text { Sultan Idris }\end{aligned}$ & $\begin{array}{l}\text { Mechanics of GZG is the same as Monopoly } \\
\text { games. The game duration is quite long, this can } \\
\end{array}$ \\
& $\begin{array}{l}\text { make the player feel anxious and reduce play } \\
\text { motivation for a long term. }\end{array}$ \\
\hline
\end{tabular}

\section{Discussion}

From the results, the respondents agree that the GZG board game can act as an effective tool for Zakat teaching and learning. It gives a positive impression to the respondents to learn about Zakat concepts. Furthermore, the majority of respondents mentioned that they enjoyed playing GZG. The researcher will take into account that GZG needs to be improved in terms of the design of the board, instructions, characters and language used. For the global market, perhaps a set with Arabic and other foreign languages should be developed. This game utilizes experiential learning in promoting Zakat understanding. Based on the observations done throughout the game, respondents were consistently focused on their objectives and committed to the game. The element of competition requires the students to communicate with each other and got all the students to be actively involved in each stages of the game. On the other hand, based on our experience, this game had assisted the instructor during the explanation and self-reflection sessions about Zakat.

From the observation and survey results, the GZG functions as a communication means for students' social interaction. The gaming process enables learners to experience, reflect on their inner characteristics, fully express and reveal their emotions, ideas, experiences and behaviours, which in turn foster the strength to change and mature. As the GZG is embedded with metaphorical teachings, interpersonal communication, self-involvement, game immersion, and emotional liberation functions, players can reflect on key elements such as teamwork, trust, responsibility, problemsolving, decision-making, leadership, goal setting, and communication.

There are various teaching and learning methods used at school level in applying knowledge to students. The gamification method in education is widely used in Malaysia, as well as abroad as it gives students an understanding on a topic. Although board games generally have a shorter game time and complexity as opposed to other common games, for example, simulation online games, these same characteristics make them better suited for the use in a classroom context. In fact, board games have been used as teaching materials since ancient times because while playing them, players get to increase their critical thinking, problem-solving, analysis, reasoning, planning and communication skills (Hinebaugh, 2009). Also, it can foster collaborative and communication abilities by requiring intensive teamwork while solving conflicts during gameplay. In the same vein, a few respondents in this study highlighted the importance of downtimes that commonly happen in board games, such as when players wait for each other's moves, saying that they foster reflection, discussion and a natural clarification of the topics. 
The strengths that exist in the method of education through gamification and regular schooling systems are complementary to each other. Applying gamification in learning is an important new alternative and needs to be applied in the existing educational system today. These two unified elements can lead to an important outcome for building diverse skills in the $21^{\text {st }}$ century. Gamification is able to motivate students to stay active in the classroom, help teachers prepare teaching materials, create a medium of appreciation for students and draw their attention to being more focused and advanced in the lesson. This method is also able to show them that learning is something that is interesting and exciting.

The Islamic education world puts the right and accurate information as a fundamental principle needs to be emphasized. The existence of gamification methods in education helps ease the process of delivering Islamic sciences loaded with source links and Quranic verses and Hadiths. New innovations introduced in the field of Zakat like GZG, can be a model and a special guide to scholars and Muslims to create a more creative and effective way of delivering knowledge. GZG is also expected to be a platform and effective missionary tool in an effort to enhance the understanding and awareness of the community on Zakat, especially in Malaysia to fulfill the third pillar of Islam.

However, it is undeniable that the challenges faced by Islamic educationalist are how they can translate Islamic ideas and understanding more effectively through the emerging technologies that are rapidly developing without altering and reducing the core of debates and Islamic knowledge to be delivered. Hopefully by introducing GZG at every level of society, particularly in educational institutions, will be the trigger for innovation in the context of Islamic education that implements the concept of education while playing and entertaining.

\section{Conclusion}

GZG is not just a matter of use for Malaysians only, but it is inclusive and can be used by people regardless of race. This global nature exists when GZG is not only created in Malay, but even English and Arabic versions. The goal of developing creative methods in the Islamic education world needs to be achieved and inspired by all researchers and communities who not only want to see the fiqh of Zakat, but the whole of Shari'a knowledge is understood and translated by practice based on clear and true understanding.

\section{Acknowledgement}

The authors gratefully acknowledge Ministry of the Higher Education of Malaysia for the research project financial support under Prototype Research Grant Scheme (PRGS) number PRGS/1/2017/SSI03/USIM/02/1 and Research Management Centre, USIM grant number USIM/PRGS/INFAD/FSU/055002/50117.

\section{Corresponding Author}

Nurkhamimi Zainuddin, Universiti Sains Islam Malaysia, khamimi@usim.edu.my, Universiti Sains Islam Malaysia, Bandar Baru Nilai 71800, Nilai, Negeri Sembilan, Malaysia 
INTERNATIONAL JOURNAL OF ACADEMIC RESEARCH IN BUSINESS AND SOCIAL SCIENCES

Vol. 9, No. 3, March, 2019, E-ISSN: 222 2-6990 ¿ 2019 HRMARS

\section{References}

Ab.Rahman, A., Ibrahim, I. H., Abidin, T. M. T. Z., \& Fauzi, A. A. M. (2017). Gamification in Islamic education based on Global Zakat Game: Bijak zakat version 1.0 (GZG). Al-Qanatir: International Journal of Islamic Studies, 6(1), 1-9.

Carlos, M. Z. J., \& Awad-Aubad, G. (2007). Requirements game: Teaching software project management. CLEI Electronic Journal, 10(1).

Charsky, D. (2010). From edutainment to serious games: A change in the use of game characteristics. Games and culture, 5(2), 177-198.

Cook, L. S., \& Olson, J. R. (2006). The sky's the limit: An activity for teaching project management. Journal of Management Education, 30(3), 404-420.

Hinebaugh, J. P. (2009). A board game education. R\&L Education.

Lee, H. L. J. (2016). SMARTies: Using a board game in the English classroom for edutainment and assessment. Malaysian Journal of ELT Research, 8(1), 35.

Reid, M., Brown, S., \& Tabibzadeh, K. (2012). Capstone teaching models: Combining simulation, analytical intuitive learning processes, history and effectiveness. Journal of Education for Business, 87(3), 178-184.

Treher, E. N. (2011). Learning with board games. The Learning Key Inc.

Wahab, A. A., \& Borhan, J. T. (2014). Faktor penentu pembayaran zakat oleh entiti perniagaan di Malaysia: Satu tinjauan Teori. Jurnal Syariah, 22(3), 295-322.

Zainuddin, N., \& Idrus, R. M. (2017). From TPACK to Learning Buffet: Developing a New Model for Open and Flexible Learning. Saudi J. Human. Soc. Sci, 2(4), 344-347. 